\title{
By-Products of Examination Malpractices on Senior High School Students in the Central Region of Ghana
}

\author{
Ben Adzrolo ${ }^{1}$, Ruth Annan-Brew $(\mathrm{PhD})^{2^{*}}$, Andrews Cobbinah $(\mathrm{PhD})^{3}$, Kenneth Asamoah-Gyimah $(\mathrm{PhD})^{4}$ \\ ${ }^{1,2,3,3}$ Department of Education and Psychology, University of Cape Coast, Ghana
}

\author{
DOI: 1 10.36348/jaep.2022.v06i01.001 | Received: 22.10.2021 | Accepted: 30.11.2021 | Published: 19.01 .2022 \\ *Corresponding author: Ruth Annan-Brew \\ Faculty of Educational Foundations, Department of Education and Psychology, University of Cape Coast
}

\section{Abstract}

This paper explored students' opinions on the effects of examination malpractices on Senior High School students in Assin Districts, Central Region. The study employed a descriptive survey design with the quantitative method. The participants were made up of students from the six public Senior High Schools in Assin Districts. Proportional stratified and simple random sampling procedures had been employed to select a sample of 302 student participants which comprised 164 male students and 138 female students. A questionnaire was employed to collect the data for the study. Means, standard deviations and independent t-test statistics were used to analyze the data gathered for the study. The findings revealed that the major effect of examination malpractice on students was academic corruption followed by ineffective study habits among Senior High School students. It was concluded that in schools where a conducive environment and teaching/learning materials are not provided for effective learning, students involve themselves in examination malpractice to raise the academic image of the school. It was recommended that the Ministry of Education should provide conducive teaching and learning environment to ensure effective academic work in schools to minimize examination malpractice. Also, heads of Senior High Schools should strengthen public education on the effects of examination malpractice to minimize the menace.

Keywords: Examination malpractice, corruption, conducive environment, impersonation, collusion.

Copyright ( 2022 The Author(s): This is an open-access article distributed under the terms of the Creative Commons Attribution 4.0 International License (CC BY-NC 4.0) which permits unrestricted use, distribution, and reproduction in any medium for non-commercial use provided the original author and source are credited.

\section{INTRODUCTION}

According to Oduwaiye (2014), an examination or a test is an assessment that is planned or intended to measure a test takers' knowledge or skill, aptitude, physical fitness or classification in many other topics. Oduwaiye further stated that a test may be administered orally, on paper, on a computer or in a confirmed area that requires a test taker to physically perform a set of skills. The author again opined that examination is an organised assessment practice that presents persons with a series of tasks geared towards determining the person acquired knowledge and skills.

Examination malpractice is defined as any deliberate act of wrongdoing, contrary to the rules of examinations designed to give a candidate an undue advantage (Obo, 2008). Obo added that examination malpractice which is also called cheating is an illegal action that students take during their examinations to try to make good grades by cutting corners. According to Makaula (2018), examination malpractice is an act or irregular manner of testing candidates that disobeys the rules and conventions guiding the conduct of examinations. Makaula further stated that examination malpractice has done a lot of harm to students since many of them have neglected their books with the hope of performing the magics they have been using in various examinations to pass. To Omonijo (2010), examination misconduct is careless, unlawful or undesirable actions put up by candidates in any official assessment of his or her intellectual capability in a specific subject. In the words of Asante-Kyei and Nduro (2014), examination malpractice is a thoughtful practice of misconduct by stakeholders including academics authority, students, teachers, and parents before the examination, during the examination and post-examination to lift the academic image of the students and the school in the evaluation and assessment. According to Busayo (2008), cheating in an examination is an inappropriate and fraudulent way to obtain an undeserved advantage over the other candidates. To Bruno and Obidigbo (2012), examination malpractice is any act which the stakeholders in education; teachers, parents, students or 
Ben Adzrolo et al., J Adv Educ Philos, Jan, 2022; 6(1): 1-6

educational administrators carry out to inflate the grades of the students in examination results. Examination malpractice in the educational system of Ghana is being widely discussed and seen as the main challenge to stakeholders in education and the society at large.

Akaranga and Ongong (2013) indicated the following as effects of examination malpractices in their study: Dismissal of students from educational institutions, bad study habits, corruption, denial of admission to genuine students. Similarly, Onyechere (2008) conducted a study on examination malpractice and found the following as consequences or effects of examination malpractices:

a) Discouragement of brilliant candidates to study hard. Good candidates are curious to believe that some average students perform better in examinations through cheating. This phenomenon makes brilliant students not being serious with their books, hoping that during examination they would have access to examination questions in advance or take script notes to examination halls to answer questions and pass.

b) Deprivation of innocent students' opportunity for admission. Most students are being deprived of or denied admission by the action of corrupted students who engaged in examination malpractices, as a result, have good grades and therefore blocked the chance of the innocent students.

c) Reduction in work efficiency. Inefficiency in the job market as a result of examination malpractices has a great impact on a country's economy. This is because people who are employed to work are ineffective.

Khanje (2009), stated that consequences of examination malpractice could be experienced immediately when cheating occurred or after a long period. Some effects of malpractice affect people while others affect a whole school, the entire education system, or a country as a whole. Consequences on an individual include cancellation of students' examination results or dismissal of a teacher who involved himself/herself in examination cheating. When the case of examination cheating is severe, the perpetrators are put before the law court and subsequently prosecuted. Some culprits if convicted are made to pay necessary fines or go to prison when they do not have the means to pay the proposed amount.

Anzene (2014) observed in a study on causes and effects of examination malpractice with concern that students who indulged in examination malpractices mostly lose their moral identity and directions. Anzene stated that those individuals that indulge in examination malpractice are no more recognising ethics as worth discharging duties that are expected of them honestly. If students who involved in examination malpractices during their school days and for example became lawyers, they are likely to become ineffective and corrupt judges and lawyers who would eventually promote unfair cases simply because some of them may not be able to distinguish between who is a complainant and who is an accused individual. Anzene further contended that so long as examination cheating is rampant in the educational system, it is likely that educational institutions would have ended up in the production of doctors who would easily forget a pair of scissors, pins, blades and other surgical operation tools in the stomach of the patient after operations. Anzene again stated that this menace "examination malpractice" shall be in continuity to harvest students with good grades and distinctions in examinations but these students would not have quality knowledge in the subject or courses they offered in their respective schools and therefore perform poorly at their workplaces. The author added by saying that the educational system would persist to prepare and produce teachers who are without adequate knowledge to teach and impact good knowledge to their students and also produce incompetent lawyers who would find it very difficult to deliver good justice in our society.

Makaula (2018) conducted a study on examination malpractice and found that; indiscipline among Senior High School students, insufficient students' preparation for the examination, the desire of students to pass the examination at all cost, lack of positive self-concept, lack of good study habits, laziness on the part of students and lack of teaching and learning materials cause examination malpractice. Similarly, Nyandwi (2017) indicated in a study that factors that cause examination malpractice were; unconducive teaching and learning environment, pressure from parents/peers to pass an examination, indiscipline among students, inadequate preparation toward examination, rating of schools according to academic performance and ineffective supervision during examinations.

According to (Eze, 2012 \& Olanipekun, 2013), the following are some identified modes of examinations malpractice:

Leakage: This means that the content of the examination or part of it is disclosed before taking the examination. Usually, it involves one or more of the following: staff members of the examination authorities, printers, proofreaders, and messengers.

Impersonation: This is a situation where an individual who has not registered as a candidate for a specific examination writes an examination in place of the one who registered. Usually, this involves collusion between the chief examiner and the examination supervisors.

\section{Smuggling of Foreign Materials}

This is possibly the commonest mode or form of examination malpractice. It relates to the introduction of unauthorized materials (e.g., parts or whole 
Ben Adzrolo et al., J Adv Educ Philos, Jan, 2022; 6(1): 1-6

notebooks, textbooks, microchips and answers) into the examination hall. Foreign materials are frequently smuggled in pants, shoes, hems and bras or deposited or fixed in the hall before the examination or even smuggled in by the candidates or their aids during the examination.

\section{Copying}

Copying from other candidates work with or without permission.

\section{Collusion}

Unauthorized passing of information between candidates usually by exchanging notes or scripts. This is usually facilitated by the inadequate spacing between desks and relax supervision.

\section{Makers Malpractice \\ Deliberately changing the marks of the candidates to either inflate or deflate a candidates' original mark. This can be initiated by examination officials or candidates themselves.}

\section{Statement of the Problem}

The persistent incidence of examination misconduct has been a major concern to stakeholders of education in Ghana (Otoo, 2018). To Adebayo (2012) and Abuga (2015) examination malpractice poses a great threat to the reliability and validity of the educational assessment. Akaranga and Ongong (2013) indicated the following as effects of examination malpractices in their study: Dismissal of students from educational institutions, bad study habits, corruption, denial of admission to genuine students and lack of confidence in the certificate. Similarly, studies conducted by Otoo (2018) and Ayikpa (2016) in Ghana indicated that lack of confidence in examination bodies, underachievement in the labour market, ineffective study habit among students, dismissal of students, lazy attitude towards teaching and corruption are some of the consequences of examination malpractice. Despite the high premium placed on examinations by the National Policy on Education in Ghana, it seems that examination malpractice is not being appropriately addressed as cases of examination malpractice keep on occurring Otoo (2018). Common observations made in examinations revealed that there is mass cheating in high stake examinations such as WASSCE, however, nothing concrete has been done to reduce the problem except the cancellation of entire results or withholding of results in certain subjects. This paper sought to investigate the effects of examination malpractice on the SHS students in the Central Region, Ghana. The specific research objective was to: investigate the effects of examination malpractice on Senior High School students.

\section{Significance of the Study}

The study's findings would add up to the body of knowledge regarding the effects of examination malpractice on Senior High School Students in Assin North and Assin South Districts.

\section{METHODOLOGY}

This piece of work employed a descriptive survey design type. The target population comprised six public Senior High Schools in Assin North and South Districts in the Central Region, Ghana. The respondents used for this piece of work comprised Senior High School form 2 and 3 students. Proportional stratified and simple random sampling techniques were employed to select the respondents for the study. The sample size used for this work was 302 which was made up of 164 male students and 138 female students. The instrument used was a four-point Likert scale type questionnaire. This questionnaire was composed of two sections and contained only closed-ended items. Section A of the instrument sought the background information of the respondents' whiles Section B focused on the effects of examination malpractice on Senior High Schools students with nine items. The content and face validity of the instrument was determined by experts in Test and Measurement who matched all the items of the questionnaire with the research question and research hypothesis to ascertain whether or not the instrument measured what it was purported to measure. The comments of the supervisors serve as a guide in making necessary corrections on the instrument. The reliability of the research instrument was determined using Cronbach's Alpha (r). The reliability coefficient of the students' instrument was 0.87 . In administering the instruments, two research assistants were employed to help. Returns were received from 301 student respondents out of 302 respondents producing a response rate of 99.7 per cent for the study.

\section{RESULTS}

Question: What are the effects of examination malpractice on SHS students in Assin Districts? The findings are presented in Table 1.

Table-1: Opinion on Effects of Examination Malpractices on students

\begin{tabular}{|l|l|l|}
\hline Statements & M & SD \\
\hline
\end{tabular}


Ben Adzrolo et al., J Adv Educ Philos, Jan, 2022; 6(1): 1-6

\begin{tabular}{|l|l|l|}
\hline 1. leads to academic corruption & 2.93 & 1.09 \\
\hline 2. leads to ineffective study habits among students & 2.89 & .96 \\
\hline 3. denial of admission to deserving students & 2.87 & .99 \\
4. lack of confidence in certificate obtained by a student & 2.84 & .98 \\
5. teachers not regular at schools to teach & 2.78 & 1.11 \\
\hline 6. teachers' lackadaisical attitude towards teaching & 2.69 & 1.04 \\
\hline 7. discourages students from studying hard & 2.68 & 1.14 \\
\hline 8. students' refusal to attend classes & 2.67 & .98 \\
\hline 9. reduces healthy competition among students & 2.63 & 1.05 \\
\hline Mean of means & 2.78 & \\
\hline
\end{tabular}

Source: Field Survey, (2020)

The results of the analysis in Table 1 indicate that respondents agreed on all the items as the effects of examination malpractice on students since the mean value of all the items exceeded the standard mean value of 2.5. Academic corruption $(M=2.93, S D=1.09)$, Ineffective study habit among students $(M=2.89, S D=$ .96), denial of admission to deserving students $(M=2.87, S D=.99)$, lack of confidence in certificate obtained by student $(M=2.84, S D=.98)$, teachers not regular at schools to teach $(M=2.78, S D=1.11)$, students' refusal to attend classes $(M=2.67, S D=.98)$, reduces healthy competition among students $(\mathrm{M}=2.63$, $\mathrm{SD}=1.05)$.

\section{Hypothesis}

$H_{0}$ : There is no significant difference between male and female students with respect to effects of examination malpractice on SHSs in Assin Districts

$H_{1}$ : There is a significant difference between male and female students with respect to effects of examination malpractice on SHSs in Assin Districts

The findings are presented in Table 2

Table-2: Independent Samples t-test showing Differences in Effects of Examination Malpractice between male and female Students

\begin{tabular}{|l|l|l|l|l|l|l|}
\hline Gender & N & Mean & SD & T & Df & P \\
\hline Male & 164 & 2.78 & .59 & & & \\
\hline & & & & .219 & 299 & .827 \\
\hline Female & 137 & 2.77 & .59 & & & \\
\hline
\end{tabular}

p > .05 significant level Source: Field Survey, (2020)

The results of the independent samples t-test indicated that there was no statistically significant difference in the mean score on effects of examination malpractice for male students $(M=2.78 ; S D=.59)$ and female students $(M=2.77 ; S D=.59), \mathrm{t}(299)=.219, \mathrm{p}=$ .827. I failed to reject the null hypothesis $\left(\mathrm{H}_{0}\right)$ which stated that there is no significant difference between the male and female students concerning effects of examination malpractice as the sig. value of .827 is greater than the alpha value of 0.05 ( $p>0.05)$. This implies that the male and female students' opinion on effects of examination malpractice was similar.

\section{DISCUSSIONS}

The foregoing indicates the analysis of the data collected for the present paper. As indicated in the findings, one of the major effects of examination malpractice in Senior High School was academic corruption. This finding might have emerged as a result of the negative attitude of the students toward teaching and learning activities in schools. It could be inferred from this finding that the respondents are aware that when teaching and learning activities are not carried on effectively in schools, students engage in examination malpractices to lift the image of the school. This finding conforms with Adelakum and Lawal (2008) who found that one of the consequential effects of examination malpractices is corruption. Another effect of examination malpractice agreed on by the students was "Ineffective study habit among students". It was agreed by student' respondents that examination malpractice led to ineffective study habits among SHS students. It could be that some students put up a lackadaisical attitude toward learning because they have it in their mind that during the examination period, they would have answers to examination questions to write and pass. The finding is in line with Khanje (2009). He noted in his study that ineffective study habit is one of the effects of examination malpractice.

Denial of admission to deserving students. The students agreed that some students are denied admission into tertiary institutions because of high grades that some students might have acquired through examination malpractice. This phenomenon may block the chance of the truthful students who did not engage in examination malpractice and have low grades in their WASSCE. This result is in agreement with Petters and Okon (2014) who found out in their study that examination malpractices lead to denial of admission to deserving students. Akaranga and Ongong (2013) reemphasised the findings by indicating in their study that 
Ben Adzrolo et al., J Adv Educ Philos, Jan, 2022; 6(1): 1-6

one of the effects of examination malpractices is "refusal of admission to deserving students".

Again, the respondents agreed that "reduction in healthy academic competition among students was one of the effects of examination malpractice. The finding could have emerged as a result of lazy attitudes toward learning that are displayed by some students even in examination periods. It could also be that some students do not care about learning toward high stake examination since they are aware of engaging in examination fraud to pass their examinations. This finding is in agreement with Nnam and Inah (2018). In their study, they found a reduction in healthy academic competition as one of the consequences of examination malpractice.

Lack of confidence in the certificate. It has been seen from the study that students agreed that one of the effects of examination malpractices was "lack of confidence in certificate obtained by students". It could be that the respondents know some people who do not perform their functions effectively on their jobs despite the good certificate they have. It could also be that the employees' certificates are not credible, they might have obtained these certificates through examination malpractice. This finding is in conformity with Petters and Okon (2014) who indicated in their study that examination malpractices lead to a lack of confidence in certificates obtained by students.

\section{Difference between Male and Female Students about effects of Examination Malpractice}

It is right to think that because of the biological differences between males and females, there should be differences in their opinion about the effects of examination malpractice. The question that arises is whether the difference is significant or not. This paper revealed that the difference that existed between male and female SHS students concerning the effects of examination malpractice was not significant. The result of the study is supported by the findings of Olatoye (2006) who found in a study that there was no significant difference between male and female students in the second cycle institutions in Ondo State about effects of examination malpractice. In Olatoye's study on effects of examination malpractice, it was found that; females $(M=2.84, S D=0.75)$ and male $(M=$ $2.56, S D=0.90)$. Although a difference existed in their opinion about effects of examination malpractice it was not significant $(\mathrm{df}=220, \mathrm{t}=-2.429, \mathrm{p}=0.283)$.

\section{CONCLUSIONS AND RECOMMENDATIONS}

It was concluded based on the findings that in schools, where a conducive environment is not provided for effective academic work, students' performance always falls below what is expected by the school. So, to achieve academic success, students involve themselves in examination malpractice to raise the academic image of the school. Based on findings and conclusions the following recommendations are made: The school authorities should provide conducive teaching and learning environment to ensure effective academic work in schools and also heads of Senior High Schools should strengthen public education for students on the effects of examination malpractice in Assin Districts to reduce examination malpractice.

\section{REFERENCES}

- Adelakum, A. A., \& Lawal, D. A. (2008). Examination malpractice: A major challenge to public examinations in Nigeria. (The WAEC experience). Paper presented at 26th AEAA Annual conference, Accra, Ghana.

- Akaranga, S. I., \& Ongong, J. J. (2013). The phenomenon of examination malpractice: An example of Nairobi and Kenyatta Universities. Journal of Education and Practice, 4(18), 87-96.

- Anzene, S. (2014). Trends in examination malpractices in Nigerian educational system and its effects on the socio-economic and political development of Nigeria. Asian Journal of Humanities and Social Sciences, 2(3), 1-8.

- Asante-Kyei, M. \& Nduro, S. B. (2014). Causes of examination misconducts in Secondary Schools. Journal of Education and practice, 8 (20), 1-12.

- Ayikpa, J.A., 2016. Examination Malpractices in Schools. Paper presented at the senior staff seminar, Ministry of Education, Ekiti, Nigeria March, pp: 2-9.

- Bruno, U., \& Obidigbo, G. (2012). The counselling implications of examination malpractices among university undergraduates. Research Journal of Organizational Psychology and Educational Studies, 1(2), 199 - 202.

- Busayo, I. (2008). Library intervention strategies against examination malpractices in a tertiary education institution. In N. Achebe, (Ed.), Library and Information Literacy for Higher Education. 2Pnd Ped. (pp. 65-89). Enugu, Nigeria: Nigeria Library Association.

- Eze A.K., \& Olanipekun, B. (2013). Examination and students' performance. Vanguard 19 (5167), Thursday, January 16:30.

- Khanje, C. K. (2009). The Malawi National Examinations Board: Evils of corruption in examinations. Zomba, Malawi: Malawi National Examinations Board.

- Makaula, F.B. (2018). Perceived causes and methods of examination malpractice in the Malawian education system: A case study of secondary schools in the South East Education Division (SEED). Journal of Education and practice, 6 (20), 1-7.

- Nnam, M. U., \& Inah, A. F. (2018). Empirical investigation into the causes, forms and consequences of Examination malpractice in Nigerian Institutions of Higher Learning. 
International Journal of Novel Research in Humanity and Social Sciences 2(1), 52-62.

- Nyandwi, M. D. (2017). Determinants of poor academic performance of secondary school students in Sumbawanga District. Tanzania. Unpublished thesis.

- $\quad$ Obo, F.E. (2008). Education stakeholders' attitudes towards examination malpractice and their preferred intervention strategies in Cross River State secondary schools' system, Nigeria. Unpublished PhD Dissertation). University of Calabar, Cross River State.

- Oduwaiye, D.O. (2014). Ethics and professionalism in academics. Paper presented at the Faculty of Education Seminar, University of Ado-Ekiti, Nigeria on $16^{\text {th }}$ May, 2-7.

- Olatoye, R.A. (2006). Checking the menace of examination malpractice: A call for more teaching and learning in schools. Retrieved October 15, 2010 ,

from

http://www.naere.org/journal/volums,/nco.1

- Omonijo, D.O. (2010). Parental influence onwards in an escalation of examination misconduct in Nigeria. European Journal of Social Sciences, 19(2), 297-309. Onyechere, I. (2008). Examination fraud. Retrieved June 20, 2011, from http://www.egoboosterbooks.files.wordpress.com

- Otoo, A. (2018). Students' perception of causes of examination malpractices in Junior High Schools in

- Petters, J. S., \& Okon, O. (2014). Students' perception of causes and effects of examination PhD Dissertation). University of Calabar, Cross River State. Sumbawanga District. Tanzania. Unpublished thesis. 